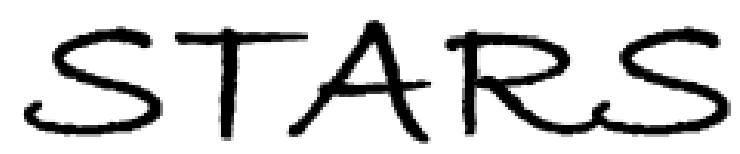

University of Central Florida

STARS

Faculty Scholarship and Creative Works

10-1-1972

\title{
The Impact of Deism on the Hebrew Literature of the Enlightenment in Germany
}

M Pelli

Find similar works at: https://stars.library.ucf.edu/ucfscholar University of Central Florida Libraries http://library.ucf.edu

This Paper is brought to you for free and open access by STARS. It has been accepted for inclusion in Faculty Scholarship and Creative Works by an authorized administrator of STARS. For more information, please contact STARS@ucf.edu.

\section{STARS Citation}

Pelli, M, "The Impact of Deism on the Hebrew Literature of the Enlightenment in Germany" (1972). Faculty Scholarship and Creative Works. 63.

https://stars.library.ucf.edu/ucfscholar/63

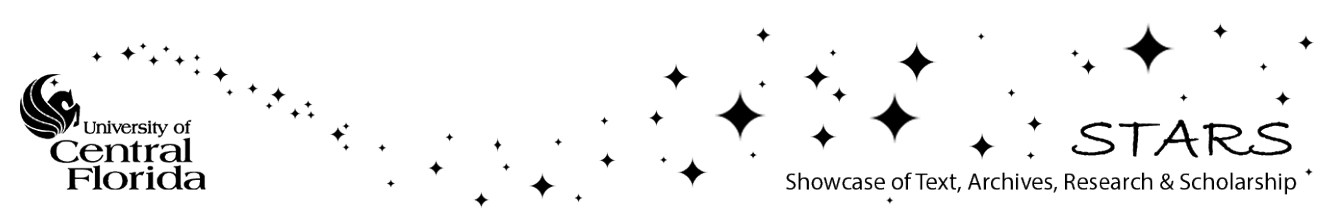




\section{American Society for Eighteenth-Century Studies (ASECS)}

The Impact of Deism on the Hebrew Literature of the Enlightenment in Germany Author(s): Moshe Pelli

Source: Eighteenth-Century Studies, Vol. 6, No. 1 (Autumn, 1972), pp. 35-59

Published by: The Johns Hopkins University Press. Sponsor: American Society for Eighteenth-Century Studies (ASECS).

Stable URL: http://www.jstor.org/stable/3031561

Accessed: 16-03-2017 13:06 UTC

JSTOR is a not-for-profit service that helps scholars, researchers, and students discover, use, and build upon a wide range of content in a trusted digital archive. We use information technology and tools to increase productivity and facilitate new forms of scholarship. For more information about JSTOR, please contact support@jstor.org.

Your use of the JSTOR archive indicates your acceptance of the Terms \& Conditions of Use, available at

http://about.jstor.org/terms

American Society for Eighteenth-Century Studies (ASECS), The Johns Hopkins University Press are collaborating with JSTOR to digitize, preserve and extend access to EighteenthCentury Studies 


\title{
The Impact of Deism on the Hebrew Literature of the Enlightenment in Germany
}

\author{
MOSHE PELLI
}

The European Enlightenment was not in essence atheistic, ${ }^{1}$ nor was it irreligious, ${ }^{2}$ though manifestations of free thought, atheism, and materialism were an integral part of it. Its most characteristic religious expression is deism, considered by some scholars to be "the religion of the Enlightenment."3 It was deism that developed and crystallized the idea of natural religion, whose architects had been John Selden (1584-1654) and Hugo Grotius (15831645). Deism attached a new, universal dimension to religion, and was one of the decisive factors in the weakening of orthodox religious values in Europe as well as in the weakening of the Christian church. A study of the deistic movement in England, France, and Germany reveals that it is not to be regarded as having one, unified, homogeneous Weltanschauung. Nevertheless, one has to resort to generalizing in order to present the attitude of the European Enlightenment toward religion-religion in general, and the Christian religion in particular-as expressed in one of the most influential and most notable movements in European thought during the latter part of the seventeenth century and the eighteenth century; the impact of this movement on the Hebrew Enlightenment in Germany is noticed only in the late eighteenth and the earlier nineteenth centuries.

Unlike the Renaissance, which attempted to understand religious dogma, and to interpret it in a humanistic fashion, European En-

1 Paul Hazard, European Thought in the Eighteenth Century (New York, 1963), p. 129.

2 Ernst Cassirer, The Philosophy of the Enlightenment (Boston, 1965), pp. 13536. Of the same opinion is Herbert Dieckmann in "Themes and Structure of the Enlightenment," Essays in Comparative Literature (St. Louis, 1961), pp. 67 ff.

3 John Hibben, The Philosophy of the Enlightenment (New York, 1910), p.272. See also Arthur O. Lovejoy, "The Parallel of Deism and Classicism," Essays in the History of Ideas (Baltimore, 1948), p. 79. 
lightenment treated religion in general skeptically and critically. ${ }^{4}$ The methods of objective criticism were transferred from the realms of philosophy and the sciences to theological thought as well as to the study of history and the examination of the sources of religion, i.e., the sacred scriptures. Comparative study of the oriental religions and the three major Western ones developed; and with the discoveries of parallel aspects in their basic beliefs and worships, Christianity appeared less original than previously thought. Theological reasoning changed: a critical approach to all religious matters-the scriptures and their authenticity, dogmas and their truth, ways of worshiping and their origins. Thus European Enlightenment in the seventeenth and eighteenth centuries made critical-skeptical reason the criterion for the phenomena of life. The proper study of mankind, as Alexander Pope remarked, was $\operatorname{man}^{5}$ - in his attitude toward reality, past and present, and his attitude toward society and God.

Generally speaking, the Enlightenment did believe in the existence of a transcendental being, supreme in his power, goodness, and wisdom, who had set up world order, but who in no way has the capacity to change it, nor to exercise any providence over any person; ${ }^{6}$ his existence can be proved by human reason ${ }^{7}$ (the watch testifies to the existence of its maker), which is also the discoverer of natural religion and natural law. This world is the best possible, a fact which, however, does not preclude an after-life. The Enlightenment further maintained that every individual may think freely in matters of religion, independent of any scriptural or ecclesiastical authority; the only basis for human thought must be natural phenomena explained in a natural, scientific way. By the same token, religious truths, too, are arrived at through man's own experience without any divine or authoritative interference.

4 Cf. Cassirer, pp. 137-38.

5 An Essay on Man, II, 1-2.

${ }^{6} \mathrm{~S}$. G. Hefelbower is of the opinion that most deists did believe in divine providence. See The Relation of John Locke to English Deism (Chicago, 1918), p. 92. This view is surely right with regard to the first deists.

7 Samuel Hugo Bergman, in his Hogim Uma'aminim [Thinkers and Believers] (Tel Aviv, 1959), p. 10, explains why deism ignored one of the most important aspects of religious life - the religious experience. In its desire to form a natural religion, a religion of reason, deism intentionally gave up any encounter, or meeting, with the divine (which they called revelation). Roland N. Stromberg, too, criticizes deism for its lack of understanding of the need of the (religious) man for emotional 
The theology of the Enlightenment is then a natural theology, as opposed to the theology of revelation. Doing away with the latter, which is based on scriptural accounts of miracles and prophecies, and of specific events that happened to historical figures, the Enlightenment left only general revelation, that universal sense of God which is independent of historical events or people.

In addition, the Enlightenment and deism deprived Christianity of its claim to be the source of morality and made it their own after waging an aggressive attack on both Christianity and Judaism. In this attack deists expressed their strong belief that morality has not always been practiced by the Christian church, that Jewish morality is rather dubious, and, most importantly, that true morality is not necessarily dependent on any religion at all.

From the contention that Christianity has no exclusive rights over true religion, deists moved on to demand religious tolerance; ${ }^{8}$ they looked for new religious values and some even envisioned the coming of a new religion altogether. ${ }^{9}$

In order to prove that natural religion preceded all other positive religions, and that it was and is the true, original form of worshiping God, the deists waged an all-out campaign against the revealed religion. They started with Judaism and anticipated as a result the automatic downfall of Christianity, which is dependent on Judaism. Hobbes, in his Leviathan, is already skeptical about the divine revelation, the scriptural miracles, and the authorship and unity of the

satisfaction, or an "inward spiritual experience," in his Religious Liberalism in Eighteenth-Century England (London, 1954), p. 64.

${ }_{8}^{8}$ Bergman (Hogim, pp. 23-24) is right in attributing the inclination toward religious tolerance to the estrangement from religion that took place in the Enlightenment period. There were instances among some of the latter deists such as Rousseau and Lessing, however, of arriving at religious tolerance as a result of its adherence to the principles of justice and brotherhood believed to be the tenets of religion.

${ }^{9}$ Gotthold Ephraim Lessing is believed to have envisioned the coming of a new religion in his Die Erziehung des Menschengeschlechts (Berlin, 1785 [facsimile, Jerusalem, 1967]), pp. 80-81, no. 86: "Sie wird gewiss kommen, die Zeit eines neuen ewigen Evangeliums, die uns selbst in den Elementarbüchern des Neuen Bundes versprochen wird." Gottfried Fittbogen discusses this view in his book Die Religion Lessings (Leipzig, 1923), p. 79, while Flajola holds the opposite view; see Edward S. Flajola, "Lessing's Attitude in the Lavater-Mendelssohn Controversy," $P M L A, 63$, No. 3 (1958), 208-9. Lessing's letter to Mendelssohn of 9 January 1771, in which the former encouraged the Jewish philosopher to reply openly to Lavater, seems to support the view that Lessing indeed wished to bring about the downfall of Christianity. See Lessing, Sämtliche Schriften (Leipzig, 1904), XVII, 364 ff., and Moses Mendelssohn, Gesammelte Schriften (Leipzig, 1844), V, 189. 
five books of Moses. ${ }^{10} \mathrm{He}$ thus preceded Spinoza in his biblical criticism and probably also influenced him. ${ }^{11}$

Among the first to examine Jewish customs and ceremonies and compare them with Egyptian laws was John Spencer. His objective was to prove the pagan nature of Judaism and hence its falsehood. ${ }^{12}$ Many deists, such as Blount, Tindal, and Shaftesbury, elaborated on this theme. ${ }^{13}$ Blount and later Collins attempted to take away from Judaism its claim of original authorship of the monotheistic idea, in order to demonstrate the truth and the antiquity of natural religion. ${ }^{14}$

Toward the end of the seventeenth century John Toland published his Christianity Not Mysterious, in which he openly stated that those Christian doctrines which appear to be mysterious, that is to say contrary to reason, are not true. ${ }^{15}$ Miracles in the Old and New Testaments can be explained according to the laws of nature ${ }^{16}$ those that contradict nature are false and the result of superstition. Thus he concludes that the Virgin Birth is fictitious. ${ }^{17} \mathrm{He}$ further shows that Catholicism cannot prove itself the true religion, since all its claims - such as its antiquity, its continuity, its miracles and prophecies-

10 Thomas Hobbes, Leviathan (Oxford, 1964), pp. 244, 247 ff., 285-86.

11 See Joseph Klausner, Philosophim Vehogei De'ot [Philosophers and Thinkers] (Jerusalem, 1965), pp. 75-76, and John Orr, English Deism: Its Roots and Its Fruits (Grand Rapids, Michigan, 1934), p. 79.

12 Paul Hazard, in The European Mind (1680-1715) (New York, 1964), p. 45, puts John Marsham (1602-1685) ahead of Spencer as the writer who started this trend, but he acknowledges Spencer's more scientific form. Samuel Ettinger, too, puts Marsham first in chronological order, but emphasizes his traditional tendencies; see his article "Jews and Judaism in the Eyes of the English Deists in the Eighteenth Century," Zion, 29, Nos. 3-4 (1964), 185-86 [Hebrew]. It is worth mentioning that chronologically Herbert of Cherbury preceded both Marsham and Spencer in discussing the influence of the Egyptian religion on the Jewish religion; his treatment of the subject was not as comprehensive as that of the other two writers. Herbert's De Religione Gentilium was first published in Amsterdam in 1663; see Edward, Lord Herbert of Cherbury, The Antient Religion of the Gentiles (London, 1705), p. 23.

13 See Charles Blount, The Oracles of Reason (London, 1693), p. 134; Blount, Religio Laici (London, 1683), p. 54. Several passages in the latter source were taken verbatim from Herbert of Cherbury's A Dialogue Between A Tutor and His Pupil (London, 1768), p. 68-a practice which was quite common with Blount. See also Matthew Tindal, Christianity as Old as the Creation (London, 1730), I, 90 (there are two 1730 editions with different pagination; for this paper I have used the edition which contains 432 pages); Anthony, Earl of Shaftesbury, Characteristics of Men, Manners, Opinions, Times (Indianapolis \& New York, 1964), II, 189-90.

${ }^{14}$ Blount, The Oracles of Reason, p. 135; Anthony Collins, A Discourse of the Grounds and Reasons of the Christian Religion (London, 1737), pp. 124-25.

15 John Toland, Christianity Not Mysterious (London, 1696); see the title page.

16 Toland, Tetradymus (London, 1720), pp. 1-60.

17 Toland, Christianity Not Mysterious, p. 152. 
are made by other religions as well, and each one maintains that it alone is the true religion and that all the others are false. ${ }^{18}$ Later, in the eighteenth century, Rousseau was to express the same idea; ${ }^{19}$ Lessing, too, has it as the main theme of his Nathan the Wise.

Anthony Collins is more blatant, attacking the church by noting the existence of controversies within it concerning doctrines and customs. Evidently these doctrines and customs cannot all be true. ${ }^{20}$ Matthew Tindal, in Christianity as Old as the Creation, abolished completely the positive law of all positive religions, ${ }^{21}$ and started the trend, of which Voltaire is the outstanding representative, of attacking the clerics, both Jewish and Christian, for corrupting their respective religions. ${ }^{22} \mathrm{He}$ cites a song, widespread in his day, which sums up briefly and clearly the deistic view:

Natural Religion was easy first, and plain;

Tales made it Mystery, Offerings made it Gain;

Sacrifices and Shews were at length prepar'd,

The Priest eat roast Meat, and the People star'd. ${ }^{23}$

He further accused the Jews of offering human sacrifices, an accusation which Voltaire was later to develop. ${ }^{24}$

Thomas Chubb argues that the doctrine of the Trinity reduces Christianity to a status lower than that of paganism. Chubb is among the deists who stress that the true religion is the moral religion. ${ }^{25}$ Thomas Morgan developed the balanced, historical study of religions, ${ }^{26}$ while Conyers Middleton gave a pungent comparative ex-

18 Toland, "The Primitive Constitution of the Christian Church," A Collection of Several Pieces (London, 1726), II, 171, 172, 174.

19 J.-J. Rousseau, The Creed of A Priest of Savoy (New York, 1957), pp. 54-55.

20 Anthony Collins, A Discourse of Free-Thinking (London, 1713), pp. 61-76.

21 Tindal, Christianity as Old as the Creation, pp. 13, 64.

22 Tindal, The Rights of the Christian Church Asserted (London, 1707), pp. 141-42, 144. Conyers Middleton, himself a critic of the Catholic Church, feels that Tindal aims to show that "Christianity ought to be abolished" ("A Letter to Dr. Waterland," The Miscellaneous Works of Conyers Middleton [London, 1755], III, 49).

${ }^{23}$ Tindal, Christianity as Old as the Creation, p. 92. It had been published previously in John Toland's Letters to Serena (London, 1704), p. 130, with slight spelling variations.

24 Ibid., pp. 95-97. Cf. Voltaire, "A Philosophical Dictionary," The Works of Voltaire (New York, 1901-1903), V, 2, pp. 285-86.

25 Thomas Chubb, "The Author's Farewell," The Posthumous Works (London, 1748), I, 178-79; Chubb, The Previous Question with Regard to Religion (London, $1725)$, pp. 6-7.

26 Cf. Leslie Stephen, History of English Thought in the Eighteenth Century (New York, 1962), I, 141-42. 
position of Roman Catholicism, showing its direct borrowing from pre-Christian Roman paganism. ${ }^{27}$ Similarly effective techniques are to be found in the writings of the French Bayle and Voltaire.

The deistic movement in France was, generally speaking, more aggressive and more destructive than its counterpart in England. Differences between the relatively moderate Anglican Church and strict, ossified French Catholicism may account for this phenomenon. It should be noted that in England the best intellects were on the side of the orthodoxy, whereas in France atheism was dominant among the Enlighteners, and no doubt influenced deistic thought. ${ }^{28}$ For some, such as Diderot, deism was but a stage of his development and progress toward ultimate atheism. The strong social emphasis in French criticism of religion is another factor in the aggressiveness of French deism. ${ }^{29}$

Richard Simon and his criticism of the biblical texts and of various religious customs and laws with a pagan origin, paved the way toward deism in France. ${ }^{30}$ The skeptic Pierre Bayle in his monumental Dictionnaire Historique et Critique exerted great influence over the French critics of religion, the Encyclopedists, as well as over the German deists. ${ }^{31}$ There was hardly a subject raised by later deists that Bayle had not treated, and treated very effectively. He dealt with miracles, ${ }^{32}$ and the pagan origins of Christian customs; ${ }^{33}$ he maintained that religions are the cause of terrible wars $;^{34}$ he criticized biblical figures, ${ }^{35}$ and asserted that the scriptures and biblical

27 Conyers Middleton, Dr. Middleton's Letter from Rome showing an exact conformity between Popery \& Paganism; or: The Religion of the Present Romans derived from that of their Heathen ancestors (New York, 1847); Middleton, Exact Conformity of Popery \& Paganism (New York, 1836).

$28 \mathrm{Cf}$. Stephen, History of English Thought, I, 74-75.

$29 \mathrm{Cf}$. Clifford Mortimer Crist, The Dictionnaire Philosophique. . . and the Early French Deists (Brooklyn, N.Y., 1934), p. 21.

30 Richard Simon, A Critical History of the Text of the New Testament (London, 1689); Simon, A Critical History of the Old Testament (London, 1682); Simon, The Ceremonies and Religious Customs of the Various Nations of the Known World (London, 1733-1739). See also Paul Hazard, The European Mind (1680-1715), pp. 180-97.

31 Cf. Pierre Courtines, "Notes et Documents, Some Notes on the Dissemination of Bayle's Thought in Europe," Revue Littérature Comparée, 17 (Paris, 1937), $700-702$.

32 Pierre Bayle, The Dictionary Historical and Critical (London, 1734-38), I, 87, note H. Cf. Léo Pierre Courtines, Bayle's Relations with England and the English (New York, 1938), p. 5.

33 Bayle, The Dictionary, III, 744; ibid., I, 87.

34 Ibid., I, 18.

35 Ibid., pp. 6-8, note H, 23, 44-46. 
laws are false ${ }^{36}$ all religious dogmas are fictitious that contradict either reason or moral principles. ${ }^{37} \mathrm{He}$ further believed that divine revelation cannot be proven, ${ }^{38}$ that religious coercion is contrary to religious principles, and that religious tolerance should be practiced. ${ }^{39}$ It is only natural that the French Encyclopedists borrowed unhesitatingly from Bayle's dictionary, which has been ironically dubbed "the Bible of the eighteenth century." ${ }^{40}$

Similar in its scope, but more bitter in its tone, is Voltaire's work. His whip mercilessly lashed Judaism and Christianity, priests and rabbis alike. Religious tolerance is advocated, ${ }^{41}$ while those who are to blame for the lack of it - the priests-are condemned. Religious superstitions are mocked: for instance, the foreskin of Jesus which is kept at the Puy-en-Velay church and the miraculous letter which was written in the first person by Jesus and left by him in 1771 in the church of Paimpole..$^{42}$ Superstition, which according to Voltaire was fathered by paganism and adopted by Judaism, distorted and changed the church in ancient times. ${ }^{43}$ Voltaire is highly critical of Jewish tradition, maintaining that its laws are cannibalistic, ${ }^{44}$ that ancient Jews offered human sacrifices, and that they worshipped the donkey; he also accused their women of bestiality. ${ }^{45}$

Jean-Jacques Rousseau distinguished, like Lessing and Herder, between the true worship of God, which is the same in all religions in all places at all times, and the ceremonial, external part of each individual religion, which varies with its followers. "It is a stupid

36 Ibid., II, 156, 829.

37 Bayle, "Commentaire Philosophique," Euvres Diverses (The Hague, 1737), II, 367-70.

38 See Hazard, The European Mind, p. 110.

39 Bayle, "Commentaire Philosophique sur ces Paroles de Jésus-Christ," Euvres Diverses, II, $354 \mathrm{ff}$. The controversy is over the interpretation of the verse in Luke 14:23 "And the Lord said to the servant, Go out into the highways and hedges, and compel them to come in, that my house may be filled." See also "Réflexions sur la Tolerance des Livres Hérétiques," Nouvelles de la République des Lettres, CEuvres Diverses (1727 ed), I, Juillet, 1685, article ix, pp. 335-36.

40 Howard Robinson, "Bayle's Profanation of Sacred History," Essays in Intellectual History (New York, 1929), p. 147, citing Emile Faguet.

41 Voltaire, "Dictionnaire Philosophique," CEuvres Complètes de Voltaire (Paris, 1878-79), ed. Garnier, IV (XX), 523-24; “A Philosophical Dictionary," The Works of Voltaire (New York, 1901-1903), VII, 2, pp. 108-9, article on Toleration.

42 A Philosophical Dictionary, VII, 2, pp. 17-24.

${ }^{43}$ Ibid., pp. 30-31.

44 Ibid., VI, 1, p. 86, article on Laws.

45 Ibid., V, 2, pp. 284-86. 
nonsense to imagine," he says, "that God takes special interest in the form of the priest's clothes, in the order of the words which he prays or the gestures which he does by the altar." ${ }^{46}$ Of course, such doctrines as the fall of man cannot be accepted by Rousseau. ${ }^{47}$

The extreme deistic stand, which brings deism closer to atheism, is represented by Diderot. ${ }^{48}$ The Encyclopédie, of which he was one of the editors, played an important role in spreading the seeds of skepticism in Europe and in weakening the exclusive authority of the church. ${ }^{49}$

\section{*}

In Germany, birthplace of the Hebrew Haskalah-Enlightenment - deism received its inspiration mainly from English deism and less from its French counterpart. Influenced by pietism at home, and not having to fight an orthodoxy such as French Roman Catholicism, German deism is lacking that sarcasm and aggressiveness which typify the writings of Voltaire and Diderot. In addition, the principles of Leibniz-the doctrine of harmony-and of Christian Wolff-that there is some similarity between revelation and reason -are dominant in German deism..$^{50}$ It might appear as though deism in Germany intended to preserve the Christian religion and revivify it, to make peace with it rather than to destroy it. ${ }^{51}$ German En-

46 Rousseau, The Creed of a Priest of Savoy, p. 53.

47 Cf. Cassirer, The Philosophy of the Enlightenment, p. 156.

48 Diderot's De l'Interprétation de la Nature, published in 1754, signaled the change in the author's Weltanschauung; he became an atheist.

49 Cf. Hazard, European Thought in the Eighteenth Century, pp. 212-14.

50 See Cassirer, The Philosophy of the Enlightenment, pp. 175-76; Otto Pfleiderer, The Philosophy of Religion (London, 1886-1888), I, 103. Karl Hillebrand explains the basic difference between German theological thought and that of the English and the French as resulting from different philosophies dominant in the respective countries. The French and the English "arrived by the application of the law of causality in the outer world (i.e., by reasoning and mechanical explanation) at the First Cause or Deity. The German Theists started from conscience and tried to prove the Deity by the inward revelation of the moral law as it speaks in the bosom of men; and they invoked the authority of Cartesianism as developed by Leibniz, and set forth and commented upon by Wolff, which appealed to the innate idea of a Deity as the strongest proof of its existence..." (German Thought from the Seven Years' War to Goethe's Death [New York, 1880], pp. 62-63).

51 Heinrich Heine summarizes these tendencies as follows: "From the moment that a religion solicits the aid of philosophy its ruin is inevitable. . . German scholars, besides the providing of new garments have made all sorts of experiments with her. They conceived the idea of bestowing on her a new youth.... An 
lightenment indeed developed a scientific school of biblical criticism whose intentions were serious and constructive. However, both deism and biblical criticism achieved in their way what English and French deism achieved in theirs.

German deism may be said to begin with an attack on superstition by the Dutch Balthasar Bekker ${ }^{52}$ followed by a similar attack by Christian Thomasius, and his subsequent campaign against religious intolerance on the part of the Christian church. ${ }^{53}$ Although German critics of the Bible such as Arnold, Edelmann, Baumgarten, and Michaelis defended the scriptures from the interpretations of the English and French deists, ${ }^{54}$ some of which were discussed above, they do insist on a scientific study of the text according to three criteria: authenticity of the text, and philological and historical analysis. On these bases, Michaelis reached the scholarly conclusion, which is identical with the deistic view, that we may doubt the divine inspiration of some of the New Testament books. ${ }^{55}$ It is a far cry from the traditionally unique and divine truth professed by the Church.

Semler found the biblical law to be a local law of a local religion, limited to its time. Christianity and Judaism erred in that they transferred these laws far beyond their limitations of time and place. Thus the true spirit of religion was stifled by an abundance of laws, injunctions, and ceremonies. The Hebrew Bible, according to Semler, is a national book of the Jews alone, and their God is a national God, not the God of Nature. It stands to reason-Semler is repeating what Voltaire said-that since the Jews did not believe in the immortality

endeavour was made to empty Christianity of all historical content, and thus leave nothing but morality. By this process Christianity was reduced to pure deism" ( $R e$ ligion and Philosophy in Germany [Boston, 1959], p. 88).

52 Balthasar Bekker, De Betroverde Weereld (Amsterdam, 1691); Bekker, The World Bewitched (London, 1695), I, Ch. xix, pp. 182 ff.; Ch. xx, pp. 197 ff; Ch. xxiv, pp. $244 \mathrm{ff}$.

5.3 See Andrew Dickson White, Seven Great Statesmen in the Warfare of Humanity with Unreason (New York, 1912), pp. 137-38, 155 ff., Hazard, The European Mind, pp. 172-76.

54 Gottfried Arnold, Historie und Beschreibung der Mystischen Theologie, oder Geheimen Gottes Gelehrtheit wie auch derer Alten und Neuen Mysticorum (Frankfurt, 1703); Siegmund Jakob Baumgarten, "Appendix Being an Examination of the Several Opinions of Those Who Pretend, that Abraham's Posterity Reigned in Egypt," A Supplement to the English Universal History (London, 1760), I, 328; "Remarks on the Universal History," ibid., II; Hazard, European Thought, pp. 58, 66-68.

55 Hazard, European Thought, pp. 69-70. 
of the soul, as there is no direct mention of it in the Bible, the Hebrew scriptures cannot be identified with the truth. ${ }^{56}$

Reimarus was the deist par excellence of the German Aufklärung. He was the first to relinquish the Leibnizian belief in harmony between divine revelation and reason, and to side with Bayle. Revelation whose natural origin or cause one can discern is not a result of supernatural forces. On the other hand, the divine revelation as we have it is but a human testimony of a divine revelation, which should be tested by the same criteria which are used for any other human testimony, namely, the trustworthiness of the witnesses, their moral character, as well as by the logical and ethical aspects of their testimony. It follows that the Hebrew Bible is not of divine origin, nor is the New Testament. Hence both Protestantism and Catholicism are human inventions and their laws are a distortion of the natural law. Reimarus concludes that all should return to the pure, universal natural religion. ${ }^{57}$

Lessing should be mentioned especially in connection with his plea for religious tolerance in Nathan the Wise and with his vision of a forthcoming divine revelation which will supersede Christianity and the New Testament. ${ }^{58}$

The deistic attack on Judaism had a dual purpose: (1) to point out the loose and weak foundation upon which Christianity is based, so as to do away with the Christian doctrines which are founded on the Bible and on divine revelation; (2) to combat the notion of positive religion, the symbol of religious isolation.

Even though this systematic and concentrated attack did not have an immediate effect on the great majority of Jews, for it did not reach them, in Germany the Hebrew and Jewish Enlightenment was very greatly affected by it. Some factors explaining this phenomenon should be discussed. For one, deism utilized concepts which were

56 Ibid., pp. 71-73.

57 See Pfleiderer, The Philosophy of Religion, I, 101-4; Theodore M. Greene, "The Historical Context and Religious Significance of Kant's Religion," Introduction to Kant's Religion Within the Limits of Reason Alone (New York, 1960), pp. xviixviii; Karl Barth, From Rousseau to Ritschl, being a translation of eleven chapters of Die Protestantische Theologie im 19. Jahrhundert (London, 1959), p. 122.

58 See note 9 , above. 
somehow related to the spirit of Judaism. The deistic unity of God and objection to the Trinity is a typical Jewish idea. Rejection of the doctrine of original sin and the soteriology which is based on it, as well as the idea of free will-all of these were quite familiar to the Jewish Enlighteners. In addition, there were those among the deists who identified natural religion with the laws of the Torah-the Ten Commandments and the Seven Noachian Laws ${ }^{59}$ - very much to the liking of the Maskilim ${ }^{60}$ (both Jewish and Hebrew Enlighteners). The fact that deism, unlike atheism, functioned somehow within the boundaries of religion had something to do with the readiness of the Maskilim to absorb some deistic views. Being affiliated in one way or another with Jewish tradition (especially the Hebrew Enlighteners), they considered deism a new religious movement whose aims were to change and revive rather than destroy religion; ${ }^{61}$ they saw in it the religion of European Enlightenment, coming to terms with the demands posed by a new era, based on reason and science and dedicated to tolerance. ${ }^{62}$

We shall now consider the effect that deism had on the literature of the Hebrew Enlightenment in Germany during the latter part of the eighteenth century and the first two decades of the nineteenth. It is appropriate to begin with Moses Mendelssohn, who is considered to be the "father" of the Jewish Enlightenment. Despite the

59 Some allusion to the effect that certain parts of the Mosaic Law are obligatory on everyone is to be found in John Locke's The Reasonableness of Christianity, The Sacred Classics (London, 1836), XXV, 19, and in Blount's The Oracles of Reason, p. 147.

${ }^{60}$ Moses Mendelssohn, "Schreiben an den Herrn Diaconus Lavater," Gesammelte Schriften (Berlin, 1930), Jubiläumsausgabe, VII, 11; "Letter to Johann Caspar Lavater," Jerusalem and Other Jewish Writings (New York, 1969), tr. and ed. Alfred Jospe, p. 117.

${ }^{61}$ See Mendelssohn's positive attitude toward the deists in his letter to KarlWilhelm, Hereditary Prince of Braunschweig-Wolfenbüttel, Jerusalem and Other Jewish Writings, p. 124.

62 One of the Hebrew Maskilim, Mendel Breslau, wrote an article in the first Hebrew literary journal, Hame'asef [The Collector], in 1790, in which he called on the rabbis and the spiritual leaders to assemble in order to institute certain reforms in the Jewish religion as well as in religious education. In his article Breslau encouraged his readers to walk in the footsteps of the enlightened peoples of Europe who seek the truth, worship God, and pursue tolerance. He further mentions an unnamed English writer who, among others, "called us for peace" (Hame'asef, VI [1790], 301-14). I believe Breslau alludes to Joseph Priestley who addressed the Jews as follows: "Your whole nation is to be the head of all the nations. . . . We will receive and honor you as our elder brethren. . . . Your nation is the great object towards which our eyes are directed" (Letters to the Jews [New York, 1794], p. 47; first edition, 1787). 
contention of some writers ${ }^{63}$ that Mendelssohn was a deist, it is my conclusion, after having studied both the deistic literature and Mendelssohn's writings, that Mendelssohn was not a deist. ${ }^{64}$ Though he was influenced by the deistic movement, as we shall see, and although he shared some of its views, he was hardly part of it. His philosophy of Judaism, though a product of the European Enlightenment, rejects some of the fundamental doctrines of deism. His concept of God contradicts that of the deists; ${ }^{65}$ the idea of revelation in Judaism

63 Heinrich Heine, Religion and Philosophy in Germany, p. 96: "Moses Mendelssohn saw in pure Mosaism an institution that might serve as a last intrenchment of deism; for deism was his inmost faith, his most profound conviction." John Orr refers to some of Mendelssohn's views as deistic; however, he points out the difference between the English deists and the Jewish philosopher in their attitude toward Judaism and the Hebrew Bible (English Deism, pp. 193-94). John M. Robertson calls Mendelssohn a deist but adds: "He was popular chiefly as a constructive theist" (A Short History of Freethought [New York, 1960], II, 281). Otto Pfleiderer implies that Mendelssohn, in his view, was a deist in his book The Philosophy of Religion, I, 107-8. Among the Jewish scholars, Guttmann and Kopland also write to this effect, (Isaac Julius Guttmann, Dat Umada' [Religion and Knowledge] [Jerusalem, 1955], p. 203; Louis J. Kopland, "The Friendship of Lessing and Mendelssohn in Relation to the Good-will Movement Between Christian and Jew," Central Conference of American Rabbis, 39 [1929], 370). Other Jewish scholars regard Mendelssohn's deism as unquestionable: J. Zvi Zehavi, Tenu'at Hahitbolelut Beyisra'el [The Assimilationist Movement in Israel] (Tel Aviv, 1943), p. 20; Max L. Margolin, The Theological Aspect of Reformed Judaism (Baltimore, 1904), p. 107; Walter Rothman, "Mendelssohn's Character and Philosophy," CCAR, 39 (1929), p. 323; Felix A. Levy, "Moses Mendelssohn's Ideals of Religion and Their Relation to Reform Judaism," CCAR, 39 (1929), pp. 353, 355. Some of Mendelssohn's contemporaries refer to this very subject: Johann Balthasar Kölbele accused Mendelssohn of being a deist (Mendelssohn's Gesammelte Schriften, VII [1930], 51), an accusation which is denied by Mendelssohn (ibid.; see also his denial expressed in a letter written in Yiddish-German to Elkan Herz-Gesammelte Schriften, XVI [1929], 150-51). Aaron Wolfssohn, a Hebrew Maskil, is of the opinion that Mendelssohn introduced natural religion among the Jews (Jeschurun [Breslau, 1804], p. 115). Citing this source, Barzilay wrongly asserts that Wolfssohn "regarded Mendelssohn as the founder of deism among the Jews" (Isaac Eisenstein-Barzilay, "The Treatment of the Jewish Religion in the Literature of the Berlin Haskalah," Proceedings of the American Academy for Jewish Research, 24 [1955], 55). Some other writers carelessly use the term "deistic" in their discussion of Mendelssohn's writings, which are a far cry from deism; see David Rudavsky, Emancipation and Adjustment (New York, 1967), p. 70. It is unfortunate that Rudavsky neglected to point out that the original author of the description of Mendelssohn-verbatim-is no other than Joseph Klausner in his monumental work Historia Shel Hasifrut Ha'ivrit Hahadashah [History of Modern Hebrew Literature] (Jerusalem, 1960), I, 52.

64 I elaborated on this theme in my book Moshe Mendelssohn: Bechavlei Masoret [Moses Mendelssohn: Bonds of Tradition] (Tel Aviv, 1972). Michael A. Meyer, too, is of the opinion that Mendelssohn was no deist; see his The Origins of the Modern Jew; Jewish Identity and European Culture 1749-1824 (Detroit, 1967), p. 38.

65 Mendelssohn depicts God as an active agent in the world in general and in the history of the Jewish people in particular. See Jerusalem, pp. 62 ff. See also "The Principles of Judaism-A Credo," in ibid., p. 154. 
- according to Mendelssohn--which is manifested by the giving of the Torah, a sort of revelation of law, stands in direct opposition to the deistic concepts of both revelation and law; ${ }^{66}$ his unequivocal belief in a certain, unique, positive religion, ${ }^{67}$ too, eliminates him as a deist.

Mendelssohn Judaized-if one may use this term-a few deistic principles and rejected many others. He did absorb the preaching of the European Enlightenment with regard to natural, universal religion, religious tolerance and morality, and with regard to emphasis on reason and a historical-critical approach to accepted religious beliefs and customs. However, this Maskil was bound to Jewish tradition, from which - unlike some of his followers-he could not escape. Torn as a person between two worlds, two cultures-the old and the new world, the Jewish world and the recently accessible European culture-Mendelssohn's hesitation is discernible in his writings in his rationalization of the original, orthodox, traditional Judaism.

Mendelssohn attempted a bridge between the Jewish culture which seemed to be declining in Germany and the powerful, influential, and tempting general culture of the time, the latter being a decisive factor in the decline of the former. It was a two-way bridge: on the one hand, he endeavored to bring his Jewish contemporaries closer to the new, enlightened ideas, and on the other he attempted to present the true Judaism to the outside, enlightened world. True Judaism was a far cry from the distorted image of a corrupted Mosaic religion presented by critics of religion, deists and atheists alike-as well as by Christian theologians - as a result of either bias or lack of knowledge or misconception. Nor was it the Judaism practiced by Rabbi Rephael Hacohen, the zealot ultra-orthodox contemporary of Moshe ben Menahem (Mendelssohn), considered by the Maskilim as the symbol of old-fashioned, ossified Judaism and, as a result, as their arch-enemy. ${ }^{68}$

Some deistic ideas Mendelssohn dressed in a Jewish fashion in order to make them attractive to the Jews as well as to emphasize his Leitmotif that Judaism is an enlightened religion. In an obvious allusion to the deistic rejection of revelation according to Christianity,

66 Mendelssohn, Jerusalem, pp. $61 \mathrm{ff}$.

67 Ibid., pp. $89 \mathrm{ff}$.

68 See my article "Some Notes on the Nature of Saul Berlin's Writings," Journal of Hebraic Studies, 1, No. 2 (1970), 53-57. 
he paraphrases a well-known biblical verse: "The voice that was heard at Sinai on that great day did not proclaim, 'I am the Eternal, your God, the necessary autonomous Being, omnipotent and omniscient, who rewards men in a future life according to their deeds." ""69 In its context, Mendelssohn is saying, the revelation at Sinai did not intend to bring forth eternal truths of faith-which to him are attainable by reason alone and not by miracles-but rather historical truth and laws. Similarly, the ideas of the early English deist, Lord Herbert of Cherbury, concerning the relativity of both history and tradition-one of the basic doctrines of deism-find their way into Mendelssohn's Jerusalem in the form of paraphrases in a biblical style. $^{70}$

The deistic disclaimers of the proof of faith from miracles, expressed by Hobbes, Blount, Tindal, and others, ${ }^{71}$ are said by Mendelssohn to be quite familiar to Judaism. No miracle, in Mendelssohn's Judaism, can either prove or contradict a truth of reason. He supports his view from the biblical injunction concerning a prophet, who, through miracles and other signs, is preaching idolatry. Despite the proof from the miracles and signs, this prophet is not to be followed and should be put to death. ${ }^{72}$ Further, Mendelssohn accepts the deistic critical view on the authority of prophecies ${ }^{73}$ as consonant with the view of Judaism. Accordingly, he maintains that the Talmudic law modifies and limits the biblical law concerning prophecies: to follow a prophet and his prophecies is a positive law, which does not stem from the proof that the prophecies came true, but rather from the will of the legislator, i.e., God. An analogous case is that of the two witnesses on whose testimony the court's decision lies, but which is not necessarily the truth. Mendelssohn unequivocally insists that according to the Torah miracles are not a sure identification of a mission from God $;^{74}$ this is undoubtedly a deistic position.

69 Mendelssohn, Jerusalem, p. 69.

${ }^{70}$ Lord Herbert of Cherbury, "Religio Laici," De Causis Errorum (London, 1645 [facsimile edition, Stuttgart-Bad Cannstatt, 1966]), p. 127; cf. Klausner, Philosophim Vehogei De'ot, p. 75. See Mendelssohn's Jerusalem, p. 70.

71 Hobbes, Leviathan, pp. 285-86; Blount, The Oracles of Reason, pp. 9-10; Tindal, Christianity as Old as the Creation, p. 192; Toland, "The Primitive Constitution of the Christian Church," A Collection of Several Pieces (London, 1726), II, 174.

72 Mendelssohn, Jerusalem, pp. 70-71.

73 John Spencer, A Discourse Concerning Vulgar Prophecies (London, 1665), p. 110; Hobbes, Leviathan, p. 244; Blount, Religio Laici, (London, 1683), pp. 4546; Tindal, Christianity as Old as the Creation, pp. 258-59.

74 Mendelssohn, Gesammelte Schriften, VII (1929), 43-44. 
In his attempt to present Judaism to the non-Jewish Enlighteners in their own terms, Mendelssohn argues that eudaemonism-happiness on earth and in the after-life, seen by the deists as the principal characteristic of true religion ${ }^{75}$-is actually part and parcel of true Judaism. Unlike Christianity, which denies happiness to non-believers-thus causing the deists to doubt the authenticity of Christianity, for God would never send the great majority of the human race into damnation-Judaism does allot the whole of humanity its share of happiness. ${ }^{76}$

Mendelssohn also endeavors to correct some misconceptions which are to be found in the deistic literature. Spencer, Blount, Morgan, and others developed a theory, originated by Herodotus, that the Mosaic laws are actually borrowed from the Egyptians, that God had to permit the Jews to practice these borrowed laws because they were ignorant and corrupted. In order to keep them under strict discipline - the deists asserted-he burdened them with very strict laws, with the Torah as their worst punishment. ${ }^{77}$ The rationale is said to indicate the low status of Jews among the nations. Against this background, Mendelssohn states emphatically that there exist reasonable and humane explanations for the Mosaic laws; that Judaism has a universal duty or mission-to preach and teach the true concepts of God and his attributes among the nations. ${ }^{78}$

A careful study of Mendelssohn's writings does reveal some direct borrowing from deism. There is one striking parallel between John Toland and the Jewish philosopher. The deist Toland writes: "Jesus did not, as 'tis universally believ'd, abolish the Law of Moses (Sacrifices excepted) neither in whole nor in part, not in the letter no more than in the spirit."79 And "the Jews, tho' associating with the con-

${ }^{75}$ See, for example, A. W., "Of Natural Religion, as Opposed to Divine Revelation," The Oracles of Reason, p. 198: "The Rule which is necessary to our future Happiness, ought to be generally made known to all men. But no Rule of Revealed Religion was, or ever could be made known to all men. Therefore no Revealed Religion is necessary to future Happiness."

${ }^{76}$ Mendelssohn, Jerusalem, pp. 65-66.

77 See Herodotus, The Histories (Baltimore, 1960), p. 116; Herbert of Cherbury, The Antient Religion of the Gentiles, p. 23; Herbert, A Dialogue Between A Tutor and His Pupil, p. 233; Spencer, A Discourse Concerning Prodigies, p. 8 [my pagination]; Blount, Religio Laici, p. 54; Blount, Oracles of Reason, p. 134; Shaftesbury, Characteristics, II, 181-90; Tindal, Christianity as Old as the Creation, p. 90; Thomas Morgan, The Moral Philosopher (London, 1738), I, 247-60, 268-71. Cf. Ettinger, "Jews and Judaism," p. 186; Klausner, Philosophim, p. 85.

78 Mendelssohn, Jerusalem, pp. 89-90, 104-5.

79) John Toland, Nazarenus: or, Jewish, Gentile, and Mahometan Christianity (London, 1718), p. 5. 
verted Gentiles . . . were still to observe their own Law thro-out all generations." ${ }^{\circ 0}$ An almost identical phrasing is to be found in Mendelssohn's writings: "The founder of the Christian religion never stated explicitly that he wanted to abolish the Mosaic law or exempt the Jews from it. . . . I cannot find in the New Testament any grounds permitting the dispensation of the Jews from Mosaic law, even if they embrace Christianity." 81

Parallels can also be found between Mendelssohn and Matthew Tindal's Christianity as Old as the Creation. Both identify the Jewish religious law with that of the Jewish civil law, ${ }^{82}$ both limit the obligation to adhere to the Mosaic law to the Jews themselves, ${ }^{83}$ both make it clear that compulsion in religious matters is not in accordance with the true spirit of religion, ${ }^{84}$ and both preach religious tolerance. ${ }^{85}$ It is beyond doubt that Mendelssohn was influenced by deistic thought; he mentions Herbert of Cherbury and his principles of deism, Pierre Bayle, and Toland, and he alludes to the deists in general. ${ }^{86}$ It is not surprising that Mendelssohn's library included some of the writings of Toland, Bayle, Diderot, Voltaire, and other Enlighteners-not to mention the works of such German deists as Reimarus. ${ }^{87}$

Emphasis is put in this study on Mendelssohn, for he was the spiritual leader of the Hebrew Enlighteners in Germany, who referred to him as "the Socrates of our time" and equated him with the two great

80 Ibid., p. iv.

81 Mendelssohn, Jerusalem, pp. 125-26.

82 Matthew Tindal, "An Essay Concerning the Power of the Magistrate, and the Rights of Mankind, in Matters of Religion," Four Discourses (London, 1709), p. 185; see also Tindal's The Rights of the Christian Church Asserted, pp. 149 ff. Cf. Mendelssohn's Jerusalem, p. 99. This view had been expressed earlier by Hobbes in Leviathan, which could have been their common source (ed. A. R. Waller [Cambridge, 1904], p. 259).

83 Tindal, Christianity as Old as the Creation, pp. 196-97; see also Tindal, The Power of the Magistrate, pp. 147, 184; cf. Mendelssohn's Jerusalem, pp. 98, 116-17.

84 Tindal, The Power of the Magistrate, pp. 133, 152, 190-91: Tindal, The Rights of the Christian Church, pp. 38-43, 90. Cf. Mendelssohn, Jerusalem, pp. 22-23, 34-35, 46-47.

85 Tindal, The Power of the Magistrate, pp. 241-42; Mendelssohn, Jerusalem, pp. 106-7, 117, 145-47.

86 Mendelssohn, Jerusalem, pp. 72, 37, 124; with regard to the reference to Toland see Mendelssohn's preface to the German translation of Menashe ben Israel's Vindiciae Judaeorum (the Hebrew edition of Jerusalem and other writings published in Tel Aviv, 1947, p. 150).

87 Verzeichniss der Auserlesenen Büchersammlung des Seeligen Herrn Moses Mendelssohn (Berlin, 1786 [facsimile edition, Leipzig, 1926]). 
Moseses of Judaism-Moses and Maimonides. ${ }^{88}$ Their esteem for Mendelssohn was expressed in a paraphrase of Pope's epigram on Newton: "Truth and Religion lay hid in darkness for many a generation/Till God said let there be Moses! And there was light."

A contemporary of Mendelssohn, the Hebrew writer and poet Naphtali Herz Wessely, is considered by some scholars to be the Enlightener par excellence of the period, and the literary personality that signals the beginning of the Hebrew Enlightenment. ${ }^{90}$ However, a careful and critical study of the whole of Wessely's work leads us to a different conclusion. Not only was Wessely one of the right-wing orthodox among the German Maskilim, who, rather than reforming, advocated conserving Judaism, he rejected completely the deistic trends. ${ }^{91}$ Wessely opposes the first and foremost principle of the Enlightenment-reliance on human reason. ${ }^{92}$ Aware of Wessely's antiEnlightenment views, Mendelssohn hesitated to send him his book, Phaedon, a treatise on the immortality of the soul, based on inquiry and reason. ${ }^{93}$ Wessely also attacked the deists, whom he considered worse than atheists. Worst of all are the Jewish deists "who truly know that the Torah was given by God, may his name be blessed, and who stubbornly dismiss it because of their reliance on their own wisdom and reason." ${ }^{44}$ It was only after his move from Amsterdam to Berlin, center of Hebrew Haskalah at that time, after his acquaintance with the Maskilim and after his collaboration with Mendelssohn, that Wessely produced his pro-Haskalah declaration (Divrei Shalom Ve'emet), advocating modern education for Jewish children. Apart from this, Wessely's only inclination toward the Enlighten-

88 See Heine, Religion and Philosophy in Germany, p. 94; Hame'asef, II (1785), 81: "From Moses to Moses there was no one wise like Moses"; a similar epigram had been made on other great scholars whose name was Moses, especially Maimonides. I have elaborated on this theme in my paper entitled The Image of Moses Mendelssohn As Reflected in the Early German Hebrew Haskalah Literature (Hame'asef, 1783-1797) scheduled to be published in The Proceedings of the Fifth World Congress of Jewish Studies.

89 Hame'asef, III (Tamuz, 1786), 161 [pages misnumbered; should be p. 177]. Pope's lines are, of course, "Nature and Nature's Laws lay hid in Night:/God said, Let Newton be! and all was Light!" (Poetical Works of Alexander Pope [New York, 1896], p. 475).

90 Klausner, Historia Shel Hasifrut Ha'ivrit Hahadashah, I, 10-11.

${ }^{91}$ Naphtali Herz Wessely, Levanon [Lebanon] (Vienna, 1829), pp. 44b-45a.

92 Ibid., p. 8a (in the introduction).

${ }^{93}$ Mendelssohn, Gesammelte Schriften, XVI (1929), p. 118; see also Wessely's reply, ibid., p. 122 [Hebrew].

94 Wessely, Levanon, p. 48 b. 
ment is indicated by his advancing in order of importance as well as in historical order the law of man in relation to the law of God. Wessely uses the term "Torat Ha'adam" (Law of Man). ${ }^{95}$ Almost all scholars maintain that Wessely applied this term only to the teaching of secular studies to Jewish children before their religious studies. ${ }^{96}$ Among the scholars who do not interpret the term in this way is Shapira, who equates Wessely's Torat Ha'adam with Mendelssohn's "eternal truths." ${ }^{\prime}$ (Undoubtedly Mendelssohn's influence on Wessely is seen here, even though Jerusalem was published a year after Divrei Shalom Ve'emet, for Mendelssohn's views had been well known to the Maskilim even before the publication of his book.) Eliav identifies Torat Ha'adam with "natural education," similar to that preached by the school of Pedagogic Philanthropinism in Germany. ${ }^{98}$ They all fail to note that Wessely himself identified Torat Ha'adam with the seven Noachian Laws, that is, with natural religion. ${ }^{99}$ This statement is immeasurably important to our study, for it clearly indicates that the deistic views were so powerfully influential that they gained ground even among the traditional element of the Hebrew Maskilim. Other deistic ideas, too, found their way into Divrei Shalom Ve'emet: religious tolerance, a common ground for all or most religions, which may lead to rapport and understanding among them (to Wessely, that common ground is the Mosaic Law, or the Bible).$^{100}$ Paradoxically, none of Wessely's subsequent writings reveals any inclination toward deism or toward the Enlightenment. ${ }^{101}$ Discussion of this phenomenon is beyond the scope of this paper. $^{102}$

95 Wessely, Divrei Shalom Ve'emet [Words of Peace and Truth] (Berlin, 17821785 ), p. 2a (my pagination).

96 Klausner, Zinberg, Lahover, Asaf, Scharfstein, Kaufman.

${ }^{97}$ H. N. Shapira, Toldot Hasifrut Ha'ivrit Hahadashah [The History of Modern Hebrew Literature] (Tel Aviv, 1939 [reprint, 1967]), pp. $196 \mathrm{ff}$.

98 Mordechai Eliav, Hahinuch Hayehudi Begermania [Jewish Education in Germany] (Jerusalem, 1961), p. 41. Eliav follows E. Simon in his article "Pedagogic Philanthropinism and Jewish Education," Kaplan's Jubilee Book (New York, 1953), p. 172 [Hebrew].

99 Wessely, Divrei Shalom Ve'emet, p. 2a.

100 Ibid., p. 13b.

${ }^{101}$ Editorial advice published in Nahal Habsor [The brook 'Besor,' or: good tidings] (1783); Sefer Hamidot [Book of Ethics] (1785); Ma'amar Hikur Hadin [An Essay (on) Search (or investigation) of Justice] (1788); Shirei Tif'eret [Songs of Glory] (1789-).

102 This subject, as well as others pertaining to the writings of Wessely, are discussed in my paper entitled "Naphtali Herz Wessely's Attitude toward the Jewish Religion as a Mirror of a Generation in Transition," read at the 1970 Annual Meeting of the American Academy of Religion. 
Under the influence of the Enlightenment in general and deism in particular, and with their minds set on achieving emancipation for the Jews, the Maskilim of Berlin advocated, preached, and fought for changing and modernizing the Jewish religion, the Jewish culture or civilization, as well as the Jewish way of life. ${ }^{103}$ It is necessary for our purpose to distinguish between two basic divisions among these Maskilim. There were the extremists who wrote mainly in German and the moderates who expressed themselves in Hebrew. ${ }^{104}$ The difference in language, as well as the difference in position, implies two widely different kinds of audience. The German-Jewish Maskilim catered mainly to the non-Hebraic Jewish readers, to the non-observant enlightened Jews, to the assimilationists, and to the Christian public at large. The Hebrew Maskilim aimed at their fellow Maskilim, who had stronger ties with the Jewish tradition than did the German Maskilim, and at the enlightened orthodox as well as at their opponents- the orthodox rabbis. This, however, does not preclude extremists who published in Hebrew; their extreme positions were of an entirely different nature from the ones held by the German-Jewish Enlighteners. ${ }^{105}$

Despite the distinctly deistic views expressed by such Maskilim as Saul Ascher, David Friedländer, Solomon Maimon, and Lazarus Bendavid, who used German as their principal language, and though they were instrumental in the formation of Jewish deistic thought in both languages, this paper will concentrate only on their counterparts who wrote mainly in Hebrew.

Typically, the first Hebrew Maskilim in the last decades of the eighteenth century did not begin their activities with an outright criticism of Judaism and its authority, or with a campaign for religious reform. Allowing for deviations, their career is somewhat analogous to the first steps of the early deists. When we note that all of the first generation Hebrew Maskilim-unlike their GermanJewish colleagues-came from a traditional background, a transition is to be expected. It usually started as a moderate Enlightenment in the form of laying emphasis upon wisdom and reason in matters religious, followed by attempts to reconcile Judaism and the En-

103 See my article "Intimations of Religious Reform in the German Hebrew Haskalah Literature," Jewish Social Studies, 32 (January 1970), 3-13.

104 Cf. Barzilay, "The Treatment of the Jewish Religion," p. 40; Barzilay, "National and Anti-National Trends in the Berlin Haskalah," Jewish Social Studies, 21 (July 1959), 167-68.

105 Such as Saul Berlin; see note 109, below. 
lightenment, and to show the compatibility of their religion and philosophy, and the like. Thus a Maskil like Isaac Satanow writes: "Torah and wisdom are twin sisters," 106 and "There is no belief or knowledge in the Mosaic religion which is contrary to reason."107 Subsequently, in order to prove these statements, the Maskilim had to resort to a discussion of what is known in Hebrew as Ta'amei Hamitzvot, that is, a rational explanation of the commandments in the Halachah (legal system). In so far as they did so, they followed in the footsteps of Mendelssohn, as his disciples. However, the result was beyond the expectation or the wish of Mendelssohn. For once permission was granted to reason-actually to ratiocinate-about the divine law, its temporal aspects were immediately apparent. Thus the Hebrew Enlighteners came close to some of the deistic views on the Christian as well as Jewish law.

As early as 1771 there was published the first demand to change the Jewish law according to the conditions dictated by time and place. Its author, whom I consider to be the first religious reformer of the Haskalah literature, was Mordechai Schnaber, an enlightened physician who was a contemporary of Mendelssohn. ${ }^{108}$

A distinction should be made here between the techniques of the deists and those of the early Hebrew reformers. Unlike the deists, who used arguments based on miracles and prophecies, it seemed inconceivable to their Hebrew followers to attack biblical miracles and prophecies which they considered the foundation for both Judaism and the Bible. They were never so detached from Judaism as to wish its destruction, and they revered the Bible, if not as the divine holy scripture, then as the source for Hebrew civilization-its original, uncorrupted religion, its culture, literature, history, and law.

I have found only one instance in the German Haskalah literature (in Hebrew) where miracles are questioned-not divine miracles as attested in the Bible, but rather those known to have been performed by some great rabbis. Such are the miraculous performance of Rabbi Levi who brought down beer from heaven by uttering the divine name, or the miraculous creation of the Golem, that legendary figure who saved the Jews, by the sixteenth-century rabbi of Prague. The author of this critique of miracles was Rabbi Saul Berlin, a unique phenomenon in Hebrew literature. ${ }^{109}$

106 Isaac Satanow, Mishlei 'Asaf [Proverbs of Asaf] (Berlin, 1792), II, 70a.

107 Isaac Satanow, Holech Tamim, [He Who Walks Upright] (Berlin, 1795), p. 6b.

108 Mordechai Gumpel Schnaber [George Levison], Ma'amr Hatorah Vehahochmah [An Essay (on) the Torah and Wisdom] (London, 1771), p. 2.

109 Saul Berlin, Ketav Yosher [An Epistle of Righteousness] (Berlin, 1795), p. 3b. 
The Hebrew critics of religion functioned within the framework of their religion, very much like the deists, except that their arguments were based on the Halachah, the Jewish legal system, on legal precedents and authoritative opinions. Arguments from reason alone would not have reached their target, namely the traditional element with tendencies toward the Enlightenment, as well as the traditional rabbis.

The attempt to persuade individual rabbis should be considered in light of the difference between the Christian and the Jewish religious legal systems. Generally speaking, in Judaism it is up to the individual rabbi, or to a small group of rabbis from one locality, to decide on religious matters in question, to enact religious decrees and abolish others, without the need of any hierarchical or ecclesiastical advice or consent. This is legally permissible so long as the rabbi or rabbis can support their non-heretical decision by a rabbinic authority, or a precedent, or can prove its derivation from any number of authoritative Halachic codices. Actual soliciting of favorable views and decrees from rabbis known to be sympathetic to religious reform was practiced by the Jewish reformers in 1818 in connection with religious innovations which had been instituted in the newly established reform temples of Berlin and Hamburg. ${ }^{110}$

This dissimilarity between European deism and its Hebrew equivalent is self-explanatory. But there are in the Haskalah literature a number of techniques which can be traced back to the deists. One of these is the repetitive claim by Hebrew Enlighteners that original Judaism has been distorted throughout the ages up to the present time, and that it is their duty to bring Judaism back to its pure form. ${ }^{111}$ Even the conservative Mendelssohn took part in this. He admitted openly that present-day Judaism possessed "excesses and abuses" created by men, ${ }^{112}$ and he even fought publicly, against the orthodox authorities, for banning the practice of excommunication and for an early and immediate burial of the dead. Restoration of the correct, original practices was demanded. ${ }^{113}$ These two issues became test-cases, and, in the Maskilim's view Mendelssohn triumphed,

110 See my article "The Methodology Employed by the Hebrew Reformers in the First Reform Temple Controversy (1818-1819)," Studies in Jewish Bibliography, History and Literature in Honor of I. Edward Kiev (New York, 1971).

111 See Hame'asef, II (1785), 88, 152, 154 (by an anonymous writer); "Discussion of Two Friends," V(1789), 270 (believed to have been written by Saul Berlin).

112 Mendelssohn, Jerusalem, p. 115.

113 Mendelssohn, Gesammelte Schriften, XVI (1929), $154 \mathrm{ff} . ;$ Hame'asef, II (1785), 169-74, 178-87; Mendelssohn, Jerusalem, pp. 34-35, 143-44. 
in practice, against the rabbis. This led the Maskilim to regard these two issues as the symbols of the fight for Enlightenment. They were discussed continuously for almost three decades in the literature of the German Haskalah. ${ }^{114}$

The historical-critical approach to Judaism which led to the demand to restore it to its original form may be credited with another achievement, the recognition on the part of the Hebrew Enlighteners that Judaism has always been flexible and ready for change, and that some changes have always taken place in Judaism in one way or another. What had been considered by the orthodox rabbis as Torah Shebe'al Peh, the oral law containing an elaboration of Torah Shebichtav, the written law-both traditionally thought of as having been given to Moses at Sinai-was considered by the Enlighteners as indicative of a development, a change, or even a reform of the original Mosaic religion. If this could be proved to be a legitimate practice in Jewish Halachah-according to the Maskilim's point of viewthe road was open for some changes in their own day and age. ${ }^{115}$

Their efforts were continuous and manifold. Deism is divided by Leslie Stephen into constructive and destructive (or critical) deism, ${ }^{116}$ and the efforts of the Hebrew Enlighteners may be classified in like manner. Constructively, they continued to try to persuade the orthodox rabbis on their own ground and in their own terms. Citations from rabbinic responsa literature were widely quoted by such Enlighteners as Schnaber, Berlin, Isaac Satanow, and others at the end of the eighteenth century, and by Eliezer Liebermann, Meir Bresselau, and Rabbi Aharon Chorin in the first part of the nineteenth. Also of a constructive nature was Mendel Breslau's appeal, published in 1790 in Hame'asef, the organ of the Hebrew Enlightenment, to convene an assembly of rabbis for the sole purpose of alleviating the burden of Judaism. ${ }^{117}$

This appeal unheeded, their frustrations multiplied, and the Maskilim had to resort to more effective measures. By the turn of the last decade of the eighteenth century, the situation was ripe for a change

114 For details, see notes 30 and 31 in my article "Intimations of Religious Reform in the German Hebrew Haskalah Literature."

115 Schnaber, Ma'amar Hatorah Vehahochmah, p. 2; Saul Berlin, Besamim Rosh [Incense of Spices] (Berlin, 1793), No. 251, p. 77a: the Torah itself is subject to change, and so are the principles of Judaism (p. 76b) and the oral law (p. 71a).

116 Cf. Stephen, History of English Thought, I, 76.

117 Mendel Breslau, "Michtavim Shonim" [Various Articles], Hame'asef, VI (1790), 301, 310 . 
of tactics. By then some of the Hebrew writers-Schnaber and Satanow-had published their first books, which mildly advocated the Enlightenment and which only covertly alluded to deistic views; Hame'asef and its writers were by then ignoring their promise, made public immediately after Mendelssohn's death (in 1786) to follow in his footsteps in accordance with the Torah, ${ }^{118}$ and they began publishing parables and poems which heralded new destructive and aggressive trends. ${ }^{119}$ Aware of these trends, Wessely reproached the Enlighteners in 1788 for publishing these extreme parables. ${ }^{120}$

By then, too, Rabbi Saul Berlin, ahead of his time in the extremity of his position as well as his techniques, had circulated his pungent satire Ketav Yosher in manuscript form among the Maskilim. Preceding Joseph Perl, Isaac Erter, and Judah Leib Gordon by half a century, this most talented Hebrew writer, who has unfortunately failed to get appropriate recognition from the scholars of Hebrew literature, is reminiscent of another clergyman of the English deistic movement, Conyers Middleton, as well as of Voltaire. His sharp pen is directed against the abundance of meaningless and ridiculous religious injunctions, against superstition, the Talmud, and the Kabalah. Moreover, he inverts the typical deistic argument concerning the borrowing of Jewish concepts by Christianity by saying in effect that Judaism, too, is to blame for absorbing Christian concepts. $^{121}$

In 1789, Rabbi Saul Berlin, in a disguise of orthodoxy for which he was never forgiven by either contemporary traditional rabbis or by later scholars, both of whom did not understand his predicament as the son of the revered rabbi of Berlin, led the Hebrew Enlightenment in another "first." This was a personal attack against the symbol of rabbinic authority of the time-Rabbi Rephael Hacohen of Hamburg-modeled with a great deal of innovation and ingenuity on the deistic attack against the Christian clerics. It was Voltaire's écrasez l'infâme in Hebrew attire. ${ }^{122}$ Although he published his attack under a pseudonym, Berlin's identity as the author was known

118 Hame'asef, III (1786), 212.

119 Ibid., V (1789), 194, 226, 312.

120 Ibid., IV (1788), 165.

121 Berlin, Ketav Yosher, p. 16b, concerning the connection between the coming of the Messiah and Adam's sin (i.e., original sin) in the Jewish and Christian religions. Cf. Hame'asef, VI (1790), 45.

122 [Saul Berlin], Mitzpeh Yokte'el [Watchtower of Yokte'el] (Berlin, 1789). 
to all but his father. Saul Berlin had to pay dearly for his daring: he was excommunicated by the religious court of Hamburg and was forced to leave his rabbinic post with the Frankfurt Jewish community. He vehemently fought the excommunication on a number of fronts, getting support from his father and the enlightened leaders of the Jewish community in Berlin. Considering his best defense to be outright, open attack, he published another powerful onslaught on his traditionalist adversary, Rabbi Hacohen, this time in the form of a review of the latter's book.

During all this time the Hebrew reformer was preparing his swan song: a reformed Shulhan Aruch (Jewish code of law), which he ironically attributed to a fourteenth-century rabbinic authority, Rabbi Asher ben Yehiel, known as Rosh. All his talents were put into this book, published in 1793-satire, irony, sarcasm, and his great erudition in rabbinic writings. As an orthodox rabbi of the time observed in anguish, there was hardly a religious transgression which he did not permit. In the final analysis, it appeared as though the Rosh, that strictly religious rabbi, was advocating change and reforms not only in the Oral Law but also in the Written Law-the Torah; that even such principles of Judaism as the Temple worship and the belief in the Messiah might be changed, and indeed had been changed - or had not been part of Judaism - at one point or another. A detailed analysis of the various aspects of this work, entitled Besamim Rosh, merits special attention beyond the limits of the present paper. ${ }^{123}$

Significantly, Rabbi Berlin reiterates in his book the position of his Enlightenment colleagues with regard to religious coercion, excommunication, burial, prayer in German, the exclusion of the Piyutim and Selihot (liturgical prayers) from the prayer book, and other matters. Moreover, he presents for the first time a detailed discussion of reforms, instead of the customary generalized demand for alleviating the burden or for a few changes in a number of customs.

\section{*⿻:}

As I have noted, the beginning of the 1790 s marks a turning point

123 See my article "The Religious Reforms of 'Traditionalist' Rabbi Saul Berlin (A Chapter in the History of the Struggle of Hebrew Haskalah in Germany for the Revival of Judaism)," Hebrew Union College Annual, 42 (1971) [Hebrew]. 
toward destructive trends in deistic and semi-deistic writings of the Hebrew Enlightenment in Germany. The forces from within and the development in the religious reform ideology discussed above were nurtured by European deism, as well as by German-Jewish deistic writings. It should be remembered that Saul Ascher's views on Jewish reform and his attempts to destroy the legal system in Judaism appeared in 1792 in his book entitled Leviathan; in the same year Solomon Maimon published his autobiography with its deistic theology and its critical views on Jewish customs. A year later, in 1793, Lazarus Bendavid published his deistic exposition of the Jews and Judaism, and David Friedländer, too, about this time began his deistic activities which culminated in 1799 in his infamous (from a Jewish point of view) letter to Teller, head of the Berlin Protestant Church, expressing his willingness, and that of some of his followers, to embrace Christianity under certain conditions.

In the three decades that followed, the demands for change found in Hebrew literature are not as covert. Religion is blamed by Isaac Satanow for spreading hatred in the world. ${ }^{124}$ As a result, religious tolerance is preached even among the Jews. Both are deistic ideas. Superstitious beliefs and customs are deplored in a manner reminiscent of Voltaire. The many, many religious laws, injunctions, customs, and practices encompassing every minute and every step of the Jew's life are attacked. And, finally, Jewish religious authoritythe rabbi-is being sharply criticized, especially by Saul Berlin and, some twenty years later, by such reformers as Liebermann, Bresselau, and David Caro. Concurrently, however, the Maskilim stress the importance of aspects of morality in Judaism so as to demonstrate its compatibility with deism and the Enlightenment. The writings of these Hebrew Maskilim - among others-formed and shaped under the impact of European deism, played an important role in the establishment and development of the religious reform movement in Germany, and preceded and heralded such Hebrew reformers of the 1860s and 1870s as Judah Leib Gordon and Lilienblum.

Austin, Texas 1969-Beer Sheva, Israel 1971

${ }^{124}$ Satanow, Mishlei 'Asaf, II, pp. 55a-b, Ch. 31:10, p. 77a, Ch. 42:15. 